\title{
KONSELING PRANIKAH DALAM MEREDUKSI BUDAYA PERNIKAHAN DINI
}

Dita Angraini, Yuliana Nelisma, Silvianetri, Efa Yuli Fajri

Bimbingan dan konseling SMP IT Qurrata A’yun Batusangkar

UIN Ar-Raniry Banda Aceh Jurusan Bimbingan dan Konseling

Institut Agama Islam Negeri batusangkar Prodi Bimbingan dan Konseling Pendidikan Islam

ditaangraini25@gmail.com, nelismabk@gmail.com, silvianetri.71@gmail.com

\begin{abstract}
ABSTRAK
Penelitian ini bertujuan untuk melihat tentang manfaat konseling pranikah dalam mereduksi kebiasaan pernikahan dini. Pernikahan dini adalah kekecewaan dalam mengamankan hakhak istimewa anak-anak. Konseling pranikah bertujuan untuk membantu pasangan yang ingin menikah untuk menganalisis masalah yang mengganggu di antara mereka, menjelaskan kualitas masing-masing, dan menyampaikan asumsi yang harus dicapai dalam hubungan pasangan untuk memperluas peluang untuk menjadi yang teratas dalam kehidupan pernikahan. Metode penelitian ini menggunakan pendekatan library research (Studi Pustaka). Peneliti juga mengunakan penelusuran literatur dari buku dan jurnal untuk menggali data, baik secara digital maupun manual. Hubungan yang baik di antara pasangan, cinta akan mengalir ke semua kelompok dua pemain, sehingga mereka menjadi penting dalam setiap upaya satu sama lain dalam menyelesaikan yang baik dan mencegah semua yang menjijikkan.
\end{abstract}

Kata Kunci : Konseling Pranikah, Pernikahan Dini

\section{PREMARRIAGE COUNSELING IN REDUCING EARLY MARRIAGE CULTURE}

\section{ABSTRACT}

This study aims to look at early marriage. Early marriage is a disappointment in securing the privileges of children. Premarital counseling aims to help couples wishing to marry to analyze the troubling issues between them, explain the qualities of each, and convey the assumptions that must be reached in the couple's relationship to broaden the chances of being on top in married life. This research method uses a library research approach (Library Study). Researchers also use literature searches from books and journals to explore data, both digitally and manually. A good relationship between a couple, love will flow to all groups of two players, so that they become important in each other's efforts to solve the good and prevent all the disgusting.

Keywords: Premarital Counseling, Early Marriage 


\section{PENDAHULUAN}

Segala sesuatu di alam semesta ini berbentuk dua per dua, jadi pernikahan adalah sunnatullah. Pernikahan adalah naluri manusia dalam Islam, dan itu memungkinkan seorang Muslim untuk mengharapkan komitmen terbaik bagi mereka yang umumnya memenuhi syarat untuk pelatihan dan pemeliharaan. Pernikahan menikmati tangan yang paling atas atas latihan sosial lainnya. Kepentingan sosial adalah untuk menjamin bahwa spesies manusia tetap ada, bahwa anak cucu dilahirkan, bahwa masyarakat dilindungi dari penyakit yang dapat membahayakan keberadaan manusia, dan bahwa individu menemukan harmoni jiwa. (Mubasyaroh, 2017).

Contoh pernikahan dini terjadi di banyak wilayah di planet ini dengan dasar yang berbeda. Ini telah menjadi pertimbangan area lokal di seluruh dunia mengingat bahaya yang muncul dari pernikahan yang dibatasi, seks pada usia dini, kehamilan pada usia muda, dan penyakit yang ditularkan secara fisik. Kebutuhan bukanlah variabel penting utama yang berperan dalam pernikahan dini. Hal lain yang perlu diperhatikan adalah bahaya belitan yang terjadi pada masa kehamilan dan persalinan pada usia muda, sehingga berperan dalam meningkatkan angka kematian ibu dan bayi baru lahir. Selain itu, pernikahan dini juga dapat menyebabkan masalah peningkatan karakter dan menempatkan anak-anak muda yang dilahirkan ke dunia dalam bahaya kekejaman dan pengabaian. Isu pernikahan dini adalah kekecewaan dalam mengamankan hak-hak istimewa anak-anak. Dengan cara ini, dipercaya bahwa semua pertemuan, termasuk dokter anak, akan membangun kesadaran mereka dalam menghentikan tindakan pernikahan dini (Fadlyana \& Larasaty, 2016)

Perkawinan juga merupakan fungsi mendalam yang memadukan doa-doa orang, segala sesuatunya setara, dan jenis kelamin, membutuhkan arahan, arahan dan nasihat dari para ahli dalam disiplin mereka untuk mencapai pemenuhan internal dan eksternal. Pernikahan tidak hanya didasarkan pada pemujaan, tetapi juga kesiapan fisik dan mental masing-masing pasangan. Ketika seseorang memasang, ia memasuki kehidupan lain dengan semua hasil yang menyertainya (Mubasyaroh, 2016).

Selain itu, pernikahan adalah kumpul-kumpul. Pernikahan menyatukan dua keluarga besar, baik pria maupun wanita. Mereka semua adalah orang luar, namun mereka saling mengenal, terlepas dari kenyataan bahwa mereka terisolasi oleh jarak yang serius. Pernikahan tidak hanya menyatukan dua orang di jalan, tetapi juga menyatukan dua keluarga besar dalam ikatan dan ikatan hubungan keluarga. Pernikahan tidak hanya 
didasarkan pada pemujaan, tetapi juga mencakup ketersediaan fisik dan mental masingmasing pasangan. Ketika seseorang telah menikah, maka ia memasuki kehidupan lain dengan semua hasil yang menghiasi pernikahan (Triningtyas \& Muhayati, 2017).

\section{METODE PENELITIAN}

Dalam penelitian ini menggunakan pendekatan library research (Studi Pustaka). Peneliti telah meneliti subjek pencarian literatur. Peneliti juga mengunakan penelusuran literatur dari buku dan jurnal untuk menggali data, baik secara digital maupun manual. Literatur yang dibahas berkaitan dengan konseling pranikah dalam meredukasi budaya pernikahan dini. Proses pengumpulan data tidak hanya sekedar mengumpulkan dan membaca tetapi beberapa proses seperti trianggulasi data dilakukan untuk menjaga validitas data. Sumber- sumber yang diperoleh di kumpulkan, dibaca, diselidiki, dianalisis, dicatat dan dipusatkan pada pembahasan.

\section{HASIL DAN PEMBAHASAN}

\section{Konseling Pranikah}

Konseling pranikah penting untuk dilakukan. Bimbingan pernikahan tidak kalah penting untuk diadakan dan diciptakan. Pendampingan sejak dini akan membantu pasangan dan keluarga untuk mencapai motivasi Tuhan melalui pernikahan. Pendampingan dini sebagai pendampingan yang diberikan oleh spesialis pernikahan dan individu dari kementerian untuk membantu pasangan dalam merencanakan pernikahan (Morib, 2020). Konseling dapat dijadikan sebagai pendekatan yang sangat efektif dalam membangun nilainilai spiritual bagi individu. Konseling merupakan profesi penolong yang melandasi peran dan fungsi individu pada masyarakat (Irman et al., 2020).

Latipun dalam (Irman et al., 2020) mengunkapkan bahwa konseling pranikah dianggap penting, karena awal terbinanya kehidupan rumah tangga sangat bergantung pada pembekalan awal sebelum calon pengantin melangsungkan pernikahan. Scott dalam (Irman et al., 2020) menjelaskan hasil survei yang di lakukan di Amerika, pasangan yang mendapatkan konseling pranikah tingkat perceraian mereka lebih rendah dan kepuasan pernikahan lebih tinggi, dibanding mereka yang tidak mendapat program konseling pranikah sebelum menikah. Hal ini dapat dimaknai bahwa konseling pranikah sangat penting diberikan kepada calon pengantin yang akan melangsungkan pernikahan. Konseling pranikah merupakan bagian dari konseling perkawinan dan dalam konseling Islam disebut 
dengan konseling pernikahan.

Konseling Pendampingan dini adalah program pembinaan dini yang dikenal dengan program bimbingan awal, bimbingan awal pencerahan, pengobatan dini, dan pengaturan pernikahan. Bimbingan awal adalah hubungan pembinaan yang diberikan kepada pasangan yang diharapkan untuk mengenal, memahami dan mengenali sehingga mereka benar-benar siap mental sebelum memilih untuk menikah. Selama waktu yang dihabiskan untuk mengetahui, memahami, dan menoleransi, ini tidak hanya mencakup dua kaki tangan. Bagaimanapun, hubungan ini akan mencakup keluarga yang lebih jauh dari kaki tangan yang akan datang. Sulit untuk mengakui berbagai kualitas setiap individu, dengan asumsi kita tidak memiliki petunjuk dan memahaminya dengan baik (Smith \& Lakadjo, 2018).

Pernikahan merupakan peristiwa penting dalam hidup seseorang dan diharapkan terjadi sekali seumur hidup, sehingga perlu dipersiapkan sebaik dan sematang mungkin. Hal ini dapat dilakukan konseling dengan beberapa pendekatan seperti menggunakan pendekatan humanistik (Halomoan \& Nurmaida, 2011).

Perkawinan adalah awal dari perkembangan sebuah keluarga, karena di dalamnya akan ada ayah, ibu dan anak, maka sistem yang mendasari pengaturannya yang dimulai dari seorang suami dan beberapa kebutuhan untuk mencari pertolongan agar pernikahan itu dapat berjalan dengan baik. akan selesai akan senang. Keluarga adalah kerangka kerja sosial yang khas, bekerja untuk membentuk aturan, korespondensi, dan pertukaran di antara individu-individunya. Ketiga elemen keluarga ini memiliki berbagai percabangan bagi pergantian peristiwa dan kehadiran individu-individunya. Keluarga memainkan contoh hubungan yang diulang melalui kepentingan setiap individunya. Sistem pengarahan keluarga, terutama dalam membantu menjaga hubungan keluarga, juga diperlukan untuk mengubah contoh pertukaran untuk memenuhi kebutuhan keluarga yang berubah (Manalu, 2020).

Konseling pranikah bertujuan untuk membantu pasangan yang ingin menikah untuk menganalisis masalah yang mengganggu di antara mereka, menjelaskan kualitas masing-masing, dan menyampaikan asumsi yang harus dicapai dalam hubungan pasangan untuk memperluas peluang untuk menjadi yang teratas dalam kehidupan pernikahan. Melalui bimbingan awal, pasangan menghargai bekerja pada sifat korespondensi mereka dan memanfaatkan hubungan untuk memperluas pemenuhan hubungan (Bakhtiar et al., 
2019). Selain konseling pranikah, yang juga perlu menjadi perhatian adalah perlunya monitoring terhadap kehidupan setelah menikah. Ini menjadi konseling paskanikah atau bisa disebut konseling pernikahan saja. Konseling pernikahan merupakan suatu cara bagi pasangan untuk mengingat komitmen seumur hidup mereka di hadapan Tuhan Konseling pernikahan adalah suatu bentuk terapi yang dilakukan psikiater atau psikolog terhadap kedua pasangan bersama-sama untuk menyelesaikan masalah dalam hubungan mereka (Morib, 2020)

Bimbingan pernikahan adalah kerjasama dimana seorang mentor dekat untuk membantu pasangan menikah menyelesaikan masalah yang muncul dan menjadi perhatian mereka dalam hubungan mereka; pasangan dan kaki tangan terlihat oleh pemandu serupa dalam pertemuan pelatihan yang terisolasi dan bersama yang menekankan pada masalah keluarga yang mereka hadapi (Yanti et al., 2018). Banyak pasangan saat ini memiliki masalah sepanjang kehidupan pernikahan mereka, yang kadang-kadang diremehkan, dan tidak sepenuhnya diselesaikan, misalnya, keanehan lapisan es, di mana kehidupan pasangan yang dipasang terlihat baik-baik saja, tetapi sebenarnya ada banyak hal atau masalah. masalah yang tidak. terlihat pada tingkat yang dangkal. Kemudian, pada saat itu, sekitar saat itu, sesuai rencana, masalah yang terkumpul pada akhirnya akan memicu ledakan pertempuran hebat yang pada akhirnya akan memicu pelepasan pasangan.

\section{Tujuan Konseling Pranikah}

Secara umum, tujuan yang ingin dicapai dalam proses pendampingan dini pada dasarnya adalah agar pasangan yang akan menikah dapat hidup bahagia. Secara menyeluruh tujuan pendampingan awal adalah: (1) untuk menunjukkan data kehidupan pernikahan pasangan, (2) untuk lebih mengembangkan kemampuan relasional pasangan, (3) mendorong pasangan untuk mengembangkan kemampuan kompromi, dan (4) memberdayakan pasangan untuk mendiskusikan tema. respon spesifik. Tujuan pendampingan dini yang berpusat pada pengaturan adalah: (1) pemahaman pernikahan, (2) kemampuan dalam hubungan suami-istri, (3) untuk mengatasi masalah yang akan muncul, (4) memberdayakan pasangan untuk menumbuhkan kemampuan kompromi, dan (5) membuat pasangan hidup. koneksi istri yang fantastis dan stabil untuk pernikahan yang ceria (sakinah) (Irman et al., 2020)

\section{Pernikahan Dini}

Semakin muda usia perkawinan, semakin rendah derajat pendidikan yang dicapai anak. 
Pernikahan anak sering membuat anak-anak sekarang tidak bersekolah, karena sekarang mereka memiliki tanggung jawab baru, terutama sebagai pasangan dan calon ibu, atau kepala keluarga dan calon ayah, yang diandalkan untuk memainkan lebih banyak pekerjaan berurusan. dengan keluarga hanya sebagai tumpuan keluarga dan menghasilkan uang. Contoh lain adalah karena biaya pengajaran yang terlalu mahal, anak-anak keluar dari sekolah dan kemudian ditawari untuk memindahkan beban kewajiban orang tua untuk membantu anak tersebut kepada rekannya (Adam, 2020).

Perkawinan adalah salah satu standar hidup yang mendasar yang menjadi dasar dalam afiliasi atau masyarakat yang ideal. Namun ada satu keanehan dalam pernikahan ini, yakni pernikahan dini. Keunikan ini banyak dijumpai di negara-negara non industri, salah satunya Indonesia. Alasan keanehan ini antara lain karena kesulitan keuangan, rendahnya instruksi, intimidasi dari wali, karena kecelakaan, dan karena tradisi daerah sekitar. Pernikahan dini mempengaruhi perspektif organik dan mental. Namun, dalam artikel ini kita akan memeriksa efeknya pada sudut mental. Motivasi di balik ulasan ini adalah untuk memberikan gambaran tentang pengaruh usia dini terhadap bagian mental remaja. Titik fokus ulasan ini adalah pada kaum muda karena ketidakdewasaan adalah waktu untuk mencari karakter diri (SYALIS \& Nurwati, 2020).

Faktor-faktor penyebab terjadinya pernikahan dini adalah: 1) komponen keuangan, 2) penjaga, 3) kecenderungan dan adat-istiadat daerah sekitar. Pengaruh pernikahan dini pada remaja menurut perspektif psikologis adalah berkembangnya ketakutan dan stres. Kecemasan yang dialami oleh kelompok pernikahan dini, remaja yang memiliki koneksi awal akan merasa khawatir dan terdesak dalam mengawal isu-isu yang muncul dalam keluarganya. Sementara itu, stres juga dapat menyebabkan neuritis serius karena kekecewaan yang tertunda dan karena adanya kesan stres yang berlebihan (Yanti et al., 2018).

Tingkat pendidikan lanjutan dalam aspek keuangan menengah dan atas adalah karena perkembangan awal dan menjauhkan diri dari hal-hal negatif saat berkencan, berbeda dengan pendidikan lanjutan pada aspek keuangan menengah dan bawah yang memasang karena keinginan mereka sendiri dan hubungan yang terorganisir dari orang tua mereka. karena variabel moneter. Perspektif saksi dengan tingkat pendidikan rendah di pusat dan ekonomi atas karena keinginan mereka sendiri karena telah keluar dari sekolah dan hamil tanpa kehadiran ayah, dibandingkan dengan instruksi rendah dengan tingkat keuangan yang rendah yang dipasang karena mereka kemauan sendiri dan hubungan yang terorganisir 
karena variabel keuangan keluarga. Dari pemeriksaan tersebut, cenderung disimpulkan bahwa pernikahan dini terjadi mengingat tradisi sosial lingkungan yang menjadi kecenderungan. Selain itu, tingkat sekolah dan variabel keuangan keluarga yang mempengaruhi remaja untuk menikah dini. Sejalan dengan itu, penting untuk memperluas pemahaman remaja melalui korespondensi, data, instruksi (KIE) terkait dengan pernikahan dini dan pengaruhnya pada pasangan menikah muda (Rahman et al., 2015).

Pekerjaan wali dalam memutuskan pernikahan anak dipengaruhi oleh unsur keuangan keluarga dan tingkat pendidikan keluarga. Keyakinan dan kebiasaan yang berlaku dalam keluarga dan kapasitas keluarga untuk mengelola masalah dewasa muda. Adanya dukungan keluarga terhadap koherensi pernikahan dini pada dasarnya tidak dapat dipisahkan dari tingkat informasi orang tua yang juga dapat dihubungkan dengan tingkat pendidikan keluarga. Tingkat pengajaran keluarga akan mempengaruhi pemahaman keluarga tentang kehidupan sehari-hari. Wali yang memiliki pemahaman yang rendah tentang kehidupan sehari-hari dengan melihat kehidupan sehari-hari akan membuat hubungan yang lebih baik dalam permintaan keluarga sehingga pernikahan lebih cepat menjadi jawaban utama bagi wali (Supriati, 2019).

\section{Faktor-faktor yang melatar belakangi terjadinya pernikahan dini}

1. Faktor individu, hal ini terjadi karena keinginan individu (subyek) yang dipengaruhi oleh kondisi alam yang melingkupinya. Selain itu, sapaan (pesona) dari kekasih/sayang untuk dijodohkan di usia muda karena dianggap sudah terlalu lama bertemu dengan seseorang.

2. Unsur pertimbangan wali, hal ini terjadi karena tidak adanya kontrol atau pertimbangan yang diberikan oleh wali kepada anak-anaknya. Sebagian besar dari mereka, para penjaga mengisi sebagai buruh musafir. Ketiadaan manajemen anak membuat mereka memiliki hubungan yang salah sehingga mereka akan lebih sering melakukan hubungan seksual di luar nikah. Satu lagi akibat dari hubungan seks di luar nikah yang dilakukan secara kebetulan. Dengan demikian, pernikahan di usia dini tidak bisa dihindarkan.

3. Unsur edukatif, bahwa sebagian besar orang (mata pelajaran) yang menikah di usia dini secara normal baru saja pindah dari SD/SMP/SMA. Rendahnya tingkat pendidikan yang digerakkan oleh orang (mata pelajaran), mempengaruhi contoh penalaran individu dan pengalaman yang mereka miliki. 
4. Variabel-variabel sosial lingkungan sekitar, dalam hal ini dasar dari kecenderungan sosial lingkungan, mempengaruhi keberadaan masyarakat dan keluarga secara lokal. Hal ini terjadi mengingat dampak wali, misalnya perjodohan yang menitikberatkan pada hubungan antar keluarga, gambaran tidak memiliki keinginan untuk dikenal sebagai "perawan". Kedua hal ini membuat para wali akan cukup sering mengawinkan anaknya di usia yang masih belia (I Nyoman Adi et al., 2018).

\section{Dampak psikologis yang ditimbulkan dari pernikahan dini, yaitu meliputi:}

1. Efek keuangan. Pasangan yang menikah di usia dini belum mandiri secara finansial. Berbagai kebutuhan dalam keluarga menjadi beban keuangan. Sejauh pekerjaan, mereka belum mapan dengan alasan bahwa mereka melakukan pekerjaan temporer yang tidak terspesialisasi (apa pun itu). Apalagi, tingkat pendidikan yang rendah, kurang siap untuk mencari pekerjaan baru dengan upah/gaji yang adil. Untuk mengatasi masalah hari demi hari, itu belum hilang dan ini menyebabkan ketergantungan moneter pada wali / orang tua dalam hukum (Wibowo, 2020)

2. Dampak sosial. Orang yang menikah di usia dini akan semakin sering menjadi bahan perbincangan, mengingat kesan atau cara pandang masyarakat yang kurang baik. Selain itu, pemahaman tentang pekerjaan sebagai pasangan hidup/pasangan belum dirasakan benar terbentuk karena kurangnya korespondensi yang bersahabat.

3. Efek psikologis. Kondisi emosional yang tinggi yang dialami menandakan banyaknya tekanan-tekanan yang dihadapi oleh pasangan. Adanya egoisme yang tinggi terhadap masing-masing pihak (suami/istri), hal ini rentan sering menimbulkan KDRT. Pasangan yang menikah di usia dini belum siap menghadapi peran barunya sebagai orang tua (Wibowo, 2020).

\section{KESIMPULAN}

Perkawinan adalah hubungan yang kokoh dan kokoh sepanjang kehidupan seharihari dan keberadaan manusia, bukan hanya antara pasangan dan keturunan mereka, tetapi antara dua keluarga. Hubungan yang baik di antara pasangan, cinta akan mengalir ke semua kelompok dua pemain, sehingga mereka menjadi penting dalam setiap upaya satu sama lain dalam menyelesaikan yang baik dan mencegah semua yang menjijikkan. Apalagi dengan pernikahan seseorang akan terlindung dari godaan hawa nafsunya. Pendampingan dini dilakukan sebelum pelaksanaan pernikahan. Pendampingan ini harus dilakukan oleh jemaah karena sangat penting untuk mempersiapkan calon pengantin untuk memahami motivasi di 
balik pernikahan seperti yang ditunjukkan oleh Kitab Suci. Pengarahan dini hendaknya dilakukan dalam waktu yang cukup agar pasangan benar-benar siap memasuki keluarga. Pernikahan adalah peristiwa penting dalam kehidupan seseorang dan diyakini terjadi sekali dalam bulan biru, sehingga harus siap juga dan matang seperti yang diharapkan. Ini harus dimungkinkan dengan beberapa metodologi seperti menggunakan metodologi humanistik.

\section{DAFTAR PUSTAKA}

Adam, A. (2020). DINAMIKA PERNIKAHAN DINI. AL-WARDAH. https://doi.org/10.46339/al-wardah.v13i1.155

Bakhtiar, N., Mainizar, M., Rahima MRA, R., Hasgimianti, H., \& Irawati, I. (2019). KONSELING PRANIKAH BERPERSPEKTIF GENDER PADA LEMBAGA (BP4) UNTUK MENURUNKAN TINGKAT PERCERAIAN. Marwah: Jurnal Perempuan, Agama Dan Jender. https://doi.org/10.24014/marwah.v17i2.6414

Fadlyana, E., \& Larasaty, S. (2016). Pernikahan Usia Dini dan Permasalahannya. Sari Pediatri. https://doi.org/10.14238/sp11.2.2009.136-41

Halomoan, M., \& Nurmaida, N. (2011). Analisa persepsi dan harapan terhadap konseling pranikah perkawinan. Jurnal Analitika.

I Nyoman Adi, P., Warjiman, \& Luckyta Ibna, P. (2018). Faktor-Faktor Yang Mempengaruhi Pernikahan Usia Dini Pada Remaja Wanita. Jurnal Keperawatan Suaka Insan (Jksi).

Irman, I., Murisal, M., Syafwar, F., Silvianetri, S., Zubaidah, Z., \& Yeni, P. (2020). Membangun Kesadaran Spritual melalui Konseling Berbasis Surau dalam Pengembangan Pariwisata. Islamic Counseling: Jurnal Bimbingan Konseling Islam. https://doi.org/10.29240/jbk.v4i1.1421

Manalu, E. O. (2020). Pengaruh Konseling Pranikah Terhadap Keutuhan Keluarga. Jurnal Antusias.

Morib, A. M. (2020). PENTINGNYA PELAYANAN KONSELING PRANIKAH. LOGON ZOES: Jurnal Teologi, Sosial Dan Budaya. https://doi.org/10.53827/lz.v3i1.19

Mubasyaroh. (2016). Konseling Pra Nikah Dalam Mewujudkan Keluarga Bahagia. Jurnal Bimbingan Konseling Islam.

Mubasyaroh, M. (2017). KONSELING PRA NIKAH DALAM MEWUJUDKAN KELUARGA BAHAGIA (STUDI PENDEKATAN HUMANISTIK CARL R. ROGERS). KONSELING RELIGI Jurnal Bimbingan Konseling Islam. https://doi.org/10.21043/kr.v7i2.2128

Rahman, F., Syahadatina, M., Aprillisya, R., \& Afika, H. (2015). KAJIAN BUDAYA REMAJA PELAKU PERNIKAHAN DINI DI KOTA BANJARBARU KALIMANTAN SELATAN. Media Kesehatan Masyarakat Indonesia Universitas 
Hasanuddin.

Smith, M. Bin, \& Lakadjo, M. A. (2018). Bimbingan dan Konseling Pranikah untuk Meningkatkan Persiapan Pernikahan pada Masa Dewasa Awal. Mengokohkan Peran Program Bimbingan Dan Konseling Di Perguruan TInggi Dalam Rangka Menyongsong Generasi Emas Tahun 2045.

Supriati. (2019). Hubungan Pengetahuan Dan Sikap Pada Remaja Tentang Pernikahan Dini Di Dusun Iv Desa Kolam Kecamatan Percut Sei Tuan Kabupaten Deli Serdang Tahun 2018. Jurnal Darma Agung Husada.

SYALIS, E. R., \& Nurwati, N. N. (2020). Analisis Dampak Pernikahan Dini Terhadap Psikologis Remaja. Focus: Jurnal Pekerjaan Sosial. https://doi.org/10.24198/focus.v3i1.28192

Triningtyas, D. A., \& Muhayati, S. (2017). Konseling Pranikah: Sebuah Upaya Meredukasi Budaya Pernikahan Dini di Kecamatan Pulung Kabupaten Ponorogo. JKI (Jurnal Konseling Indonesia).

Wibowo, S. E. (2020). Dampak Sosial dan Psikologis Pada Pasangan Pernikahan Dini (Studi Kasus Desa Air Balui Kecamatan Kemuning Kabupaten Indra Giri Hilir, Riau). JIGC (Journal of Islamic Guidance and Counseling). https://doi.org/10.30631/jigc.v3i2.36

Yanti, Hamidah, \& Wiwita. (2018). Analisis Faktor Penyebab Dan Dampak Pernikahan Dini Di Kecamatan Kandis Kabupaten Siak. Jurnal Ibu Dan Anak. 